(C) 2014

Спіцина Т. Л., Ракитянський В. М., Сухін В. М., кандидати ветеринарних наук Дніпропетровський державний аграрний університет

\title{
КОРЕКЦІЯ ФІЗІОЛОГІЧНОГО СТАТУСУ ТА ВІДТВОРЮВАЛЬНОЇ ФУНКЦІЇ СВИНОМАТОК ЗА ВПЛИВУ БІОЛОГІЧНО АКТИВНОЇ ДОБАВКИ
}

\section{Рецензент - доктор ветеринарних наук, професор П. М. Гаврилін}

Вивчено можливість використання біологічно активної добавки для корекиії обміну речовин та стимуляції відтворювальної функиії свиноматок. Добавка активізує білоксинтезуючу функцію печінки та покрашуе стан гепатоцитів, скорочується період між відлученням та еструсом, підвищується рівень запліднюваності після першого осіменіння на $10 \%$. Такий вплив використаної добавки сприяє покращанню кровопостачання в органах малого тазу, посилює функиіональну активність яєчників, стимулюючи фолікулогенез та овуляиію.

Ключові слова: свиноматки, добавки, еструс, відтворювання, статева функиія.

Актуальність проблеми. Покращання відтворювальної здатності свиноматок $є$ актуальним питанням у свинарстві. Скорочення періоду відлучення (охота - зменшення холостого періоду і при цьому здатність свиноматки приносити повноцінний приплід) $є$ чи не найголовнішою умовою успішного утримання дорослого поголів'я свиней. Окрім того значної уваги слід надавати профілактиці порушень статевої циклічності за умов інтенсивного виробництва [10]. Чисельні стресові фактори (порушення параметрів мікроклімату, годівлі, проведення ветеринарних i технологічних заходів) викликають гормональні зрушення у системі «гіпоталамус гіпофіз - яєчники» свиноматок, що проявляються у тимчасовій або постійній неплідності [2].

Аналіз останніх досліджень і публікацій, у яких започатковано розв'язання проблеми. На сьогодні існує чимало способів стимуляції статевої функції тварин [1]. Проте на першочергову увагу заслуговують ті методи, що $є$ більш природні, не створюють суттєвого навантаження на організм тварин, поставлених у суворі - 3 фізіологічної точки зору - умови інтенсивної технології. Саме до таких методів відноситься застосування самкам тварин препаратів, що не містять гормонів для регулювання статевої функції [3]. Останнім часом інтенсивно впроваджується у виробництво використання технології флешинг-годівлі - короткотривалої стимуляції шля- хом згодовування збільшеної кількості корму. На цьому базується також використання біологічно активних добавок із високим вмістом легкозасвоюваної енергії на основі цукрів, органічних кислот (лимонна, фумарова, бурштинова та ін.) i жирів рослинного та тваринного походження [5, $7,8]$. Доведений вплив рівня енергії раціону на вміст статевих гормонів у свиноматок $[4,6,9]$. Однак застосування таких препаратів для стимуляції відтворювальних процесів тварин в Україні значно відстає від зарубіжного досвіду [2].

Мета досліджень - виявити ефективність корекції статевої функції шляхом додавання до раціону біологічно активної добавки свиноматкам за інтенсивної технології виробництва.

Завдання досліджень:

1. Визначити вплив добавки на фізіологічний стан свиноматок.

2. Встановити ефективність застосування добавки на тривалість періоду «відлучення - еструс» у свиноматок.

Матеріали і методи досліджень. Дослідження проводилося на базі ПП Серебряков Магдалинівського району Дніпропетровської області. В досліді було залучено 20 клінічно здорових гібридних свиноматок (помісь порід велика біла х ландрас), продуктивним віком 2-3 опороси, середньої вгодованості, живою вагою 170-200 кілограмів.

Піддослідні тварини були розподілені на дві групи - контрольну та дослідну, по 10 голів у кожній. Свиноматки обох груп отримували господарські раціони, згідно з впровадженою в господарстві програмою годівлі, створені на основі БМВД із додаванням зернової групи (ячмінь, кукурудза, пшениця).

Тварини дослідної додатково із раціоном отримували біологічно активну добавку, що складалася з лимонної та фумарової кислот, декстрози й сорбітолу. Добавку згодовували щоденно, індивідуально, в дозі 130 г на тварину, починаючи $з$ третього дня до відлучення до настання статевої охоти. 
ВЕТЕРИНАРНА МЕДИЦИНА

\section{1. Біохімічні показники сироватки крові свиноматок за впливу біологічно активної добавки $(n=10, M \pm m)$}

\begin{tabular}{|c|c|c|}
\hline \multirow{2}{*}{ Показник } & \multicolumn{2}{|c|}{ Група тварин } \\
\cline { 2 - 3 } & дослідна & контрольна \\
\hline Загальний білок, г/л & $77,75 \pm 1,21^{*}$ & $73,10 \pm 1,22$ \\
\hline Альбуміни, г/л & $38,14 \pm 0,98^{*}$ & $35,12 \pm 0,86$ \\
\hline Глобуліни, Г/л & $39,16 \pm 1,25$ & $37,98 \pm 0,97$ \\
\hline АСТ, Од/л & $68,01 \pm 35,15^{*}$ & $81,18 \pm 3,32$ \\
\hline АЛТ, Од/л & $66,69 \pm 3,24$ & $79,96 \pm 5,44$ \\
\hline Глюкоза, ммоль/л & $5,39 \pm 0,21^{*}$ & $4,60 \pm 0,27$ \\
\hline Кальцій, ммоль/л & $2,94 \pm 0,08$ & $2,70 \pm 0,1$ \\
\hline Фосфор неорганічний, ммоль/л & $2,11 \pm 0,17$ & $1,81 \pm 0,09$ \\
\hline Загальні ліпопротеїни, мг/\% & $449,96 \pm 40,03$ & $549,35 \pm 30,97$ \\
\hline
\end{tabular}

Примітки: * $\mathrm{P}<0,05$ відносно контролю

На початку та вкінці згодовування добавки у тварин відбирали зразки крові для гематологічних і біохімічних досліджень, оцінювали тривалість періоду «відлучка - охота», запліднюваність.

Статистичну обробку проведено 3 допомогою програми Microsoft Excel 2003.

Результати досліджень. Після згодовування добавки у свиноматок відхилень від фізіологічних норм за біохімічними показниками крові не спостерігалось (табл. 1)

Як видно 3 наведених даних, за впливу використаних біологічно активних речовин відбулися певні зрушення в обміні речовин. Зокрема, у тварин дослідної групи вищим був рівень загального білку на $6 \%(\mathrm{P}<0,05)$, що відбулося переважно за рахунок альбумінів, концентрація яких у досліді переважала контроль на 8,5 \% $(\mathrm{P}<0,05)$.

Окрім того відбулося зниження активності ферментів переамінування - аспартатамінотрансферази (на $16,2 \%$, при $\mathrm{P}<0,05$ ) та аланінамінотрансферази (на 16,6 \%). Все це свідчить про активізацію білоксинтезуючої функції печінки та покращання стану гепатоцитів.

3 іншого боку, було зареєстровано зростання рівня глюкози у тварин дослідної групи на $17,2 \%(\mathrm{P}<0,05)$ за одночасного зниження вмісту загальних ліпопротеїдів на 18,1 \%, що вказує на покращання енергетичного статусу дослідних тварин. Зокрема, відбулася активізація синтезу вуглеводів на тлі поліпшення засвоювання ліпідів печінкою.

Як видно 3 таблиці 2, в контрольній групі за перші 10 діб після відлучення поросят еструс настав у п’яти свиноматок, тоді як у дослідній групі - у восьми. В наступні 10 діб після відлучення поросят у двох свиноматок дослідної групи еструс настав на 13-ту добу, а у чотирьох свиноматок контрольної групи він настав у середньому на 15-ту добу й в однієї свиноматки на 30-у добу.

Таким чином, використання добавки сприяє скороченню інтервалу між відлученням та проявом еструсу в середньому на 4,6 доби.

Усі свиноматки дослідної групи були продуктивно запліднені після першого еструсу, тобто запліднюваність склала 100 \%, тоді як у контрольній групі цей показник був 90 \% (у однієї свиноматки було зареєстровано повторний еструс через 21 день).

Отримані результати узгоджуються з іншими даними $[4,7,9,10]$, згідно 3 якими підвищення рівня енергії в раціоні свиней сприяло активізації статевої функції.

2. Стан статевої функції піддослідних свиноматок $(n=10)$

\begin{tabular}{|c|c|c|c|c|}
\hline & \multicolumn{3}{|c|}{ Кількість тварин з еструсом } & Інтервал між відлу- \\
\cline { 2 - 4 } Група тварин & $\begin{array}{c}\text { впродовж 4-10 діб } \\
\text { після відлучення }\end{array}$ & $\begin{array}{c}\text { впродовж 10-20 діб } \\
\text { після відлучення }\end{array}$ & $\begin{array}{c}\text { після 20-ої доби } \\
\text { після відлучення } \\
\text { ченням та еструсом, } \\
\text { дні }\end{array}$ & \\
\hline Контрольна & 5 & 4 & 1 & 12,2 \\
\hline Дослідна & 8 & 2 & - & 7,6 \\
\hline
\end{tabular}




\section{ВЕТЕРИНАРНА МЕДИЦИНА}

Крім того вуглеводи (декстроза та сорбітол) збільшують рівень у крові інсуліну й тим самим сприяють утворенню в організмі ЛГ і ФСГ $[4,6]$. Чим вище концентрація ЛГ після 14-ти днів лактації, тим коротше інтервал між відлученням та еструсом. Органічні кислоти сприяють нормалізації мікрофлори кишечника, покращуючи його моторику та перетравлення корму. До того ж вони $є$ досить цінним енергетичним субстратом i попередником багатьох біологічно активних речовин в організмі. Такий вплив використаної добавки сприяє покращанню кровопостачання в

\section{БІБЛІОГРАФІЯ}

1. Боднар О. О. Розробка комплексних схем відновлення та стимуляції відтворної функції свиноматок / Боднар О. О., Мізик В. П., Керничний С. П. [та ін.] // Наук. вісник вет. медицини. 3б. наук. праць БЦНАУ. - Біла Церква, 2010. Вип. 6(79). - С. 30-32.

2. Сухін В. М., Чумак В. О., Крива О. А. Ефективність стимуляції статевої функції у свиноматок комбінацією гонадотропінів та вітамінів / Проблеми зооінженерії та ветмедицини / Збірник наукових праць ХЗВА. - 2012. - Вип. 24. - Ч. 2. C. 240-242.

3. Харенко M.I. Інтенсифікація відтворної функції у свиней / Харенко М. І. // Здоров'я тварин і ліки. - № 1 (98). - 2010. - С. 18-19.

4. Docic A., Bilkei G. The effect of short term high feed intake on the onset of puberty in transported gilts / A. Docic, G. Bilkei // J. Swine Health Prod. - 2001. - Vol. 9 (1). - P. 25-27.

5. Dyck G. W. Factors influencing sexual maturation, puberty and reproductive efficiency in the gilt / G. W. Dyck // Can J Anim Sci. - 1988. Vol. 68. - P. 1-13. органах малого тазу, посилює функціональну активність яєчників, стимулюючи фолікулогенез та овуляцію.

\section{Висновки:}

1. Біологічно активна добавка сприяє активізації білоксинтезуючої функції печінки й стимулює вуглеводно-ліпідниий обмін у свиноматок.

2. За використання добавки у свиноматок скорочується період між відлученням та еструсом на 37,7 \%, покращується рівень запліднюваності після першого осіменіння на $10 \%$.

6. Foster D. Physiological perspectives on leptin as a regulator of reproduction: role in timing puberty / D. Foster, S. Nagatani // Biol Reprod. 1999. - Vol. 60. - P. 205-215.

7. Foxcroft G. R. Relationship between metabolism and reproduction / G. R. Foxcroft, J. R. Cosgrove, F.X. Aherne // Proc $14^{\text {th }}$ IPVS Congress. Bologna, Italy, 1996. - P. 6-9.

8. Hughes P. E. Reproduction in the gilt. 2. The influence of gilt age at boar introduction on the attainment of puberty / P. E. Hughes, D. J. A. Cole // Anim Prod. - 1976. - Vol. 23. - P. 89-94.

9. Klindt $J$. Effect of prepubertal feeding regimen on reproductive development and performance of gilts through the first pregnancy / J. Klindt, J. Yen, R. Christenson // J. Anim Sci. - 2001. - Vol. 79. P. $787-795$.

10. Wettere $W$. Management and nutrition of the replacement gilt / W. Wettere // A thesis for the degree of doctorate of philosophy. - Adelaide, Australia, 2008. - P. 274. 